\title{
Immunomodulatory action of jacalin from Artocarpus integrifolia and mannoprotein from Saccharomyces uvarum on the humoral immunity of laying hens
}

\author{
Marco Aurélio Chiara Silva ${ }^{1}$ Miriele Caroline da Silva ${ }^{1}$ João Waine Pinheiro ${ }^{2}$ \\ Raul Jorge Hernan Castro-Goméz ${ }^{3}$ Alice Eiko Murakami ${ }^{4}$ \\ Wagner Loyola ${ }^{5 *}$ Emerson José Venancio ${ }^{1}$
}

\author{
${ }^{1}$ Laboratório de Imunologia IV, Universidade Estadual de Londrina (UEL), Londrina, Paraná, Brasil. \\ ${ }^{2}$ Departamento de Zootecnia, Universidade Estadual de Londrina (UEL), Londrina, Paraná, Brasil. \\ ${ }^{3}$ Departamento de Tecnologia de alimentos, Universidade Estadual de Londrina (UEL), Londrina, Paraná, Brasil. \\ ${ }^{4}$ Departamento Zootecnia, Universidade Estadual de Maringá, Maringá, Paraná, Brasil. \\ ${ }^{5}$ Embrapa Suínos e Aves, 89700-000, Concórdia, Santa Catarina, Brasil. E-mail: wagner.loyola@embrapa.br. "Corresponding author.
}

ABSTRACT: Advances in the fields of glycobiology and immunology have provided many insights into the role of carbohydrate-protein interactions in the immune system. Jacalin of Artocarpus integrifolia (JCA) and structural mannoprotein of Saccharomyces uvarum (MPS) are molecules with immunomodulatory properties. JCA is an IgA human lectin binding molecule that causes the mitogenic stimulation of immune cells, production of cytokines, chemotaxis, and activation of leukocytes. Studies on the immunomodulatory properties of JCA and MPS in mammals and fish suggest that they have an action on antibody production. The aim of this study was to investigate the possible action of JCA and MPS on the production of specific antibodies in laying hens. For this, laying hens were inoculated with an intra abdominal injection of sheep red blood cells (SRBC) with either JCA (0.075 $\mu \mathrm{g}, 0.75 \mu \mathrm{g}$, and $7.5 \mu \mathrm{g})$ or MPS (20 $\mu \mathrm{g}$ and $100 \mu \mathrm{g})$. Levels of anti-SRBC antibodies of the IgY, IgM, and IgA classes were evaluated by ELISA. Results showed that JCA and MPS have immunomodulatory effects on levels of anti-SRBC IgM, IgA, and IgY. An immunostimulatory effect of JCA was observed in primary immune response on anti-SRBC IgY, while an inhibitory effect of JCA and MPS was observed in secondary immune response on the production of IgM and IgA anti-SRBC. These results suggested that MPS and JCA have immunomodulatory effects on antibody production and could be used in future studies on humoral immune response in poultry.

Key words: Artocarpus integrifolia, chickens, IgY, jacalin, mannoprotein, humoral immune response, Saccharomyces uvarum.

Avaliação da ação imunomoduladora do Jacalin de Artocarpus integrifolia e mannoprotein de Saccharomyces uvarum na imunidade humoral das galinhas poedeiras

RESUMO: Avanços nos campos glicobiologia e imunologia forneceram muitas informações sobre o papel das interações da proteínacarboidrato na modulação do sistema imunológico. A jacalina extraída de Artocarpus integrifolia (JCA) e a manoproteína da parede celular de Saccharomyces uvarum (MPS) são moléculas com propriedades imunomoduladoras. JCA é uma lectina com afinidade pela IgA humana e tem ação mitogênica sobre células do sistema imunológico estimulando a produção de citocinas, a quimiotaxia e a ativação de leucócitos. Estudos sobre as propriedades imunomoduladoras de JCA e MPS em mamíferos e peixes sugerem que essas moléculas podem ter um efeito sobre a produção de anticorpos. O objetivo deste estudo foi investigar a ação da JCA e MPS sobre a produção de anticorpos específicos em galinhas poedeiras. Para isso, galinhas poedeiras foram inoculadas por via intra-abdominal com eritrócitos de carneiro (SRBC) em associação com o JCA (0,075 $\mu \mathrm{g}, 0,75 \mu \mathrm{g}$, e 7,5 $\mu \mathrm{g})$ ou MPS (20 $\mu \mathrm{g}$ e $100 \mu \mathrm{g})$. Os níveis de anticorpos anti-SRBC das classes IgY, IgM, e IgA foram avaliados por ELISA. Os resultados mostraram que a JCA e a MPS têm um efeito imunomodulador sobre a produção IgY, IgM, ou IgA anti-SRBC. Um efeito imunoestimulador da JCA foi observado sobre a produção de anticorpos IgY na resposta imune primária, enquanto um efeito imuno inibitório da JCA e da MPS sobre a produção de IgM e IgA anti-SRBC na resposta imune secundária. Estes resultados sugerem que o MPS e JCA tem efeito modulador sobre a produção de anticorpos e podem ser utilizados em estudos futuros sobre a imunidade humoral em aves comerciais.

Palavras-chave: Artocarpus integrifolia, galinhas, IgY, jacalina, manoproteina, resposta imune humoral, Saccharomyces uvarum.

\section{INTRODUCTION}

Immunomodulators are molecules that exert action on the immune system, which may result in immune system activation or suppression (MASIHI \& SCHÄFER, 2011). Many immunomodulatory molecules are essential components of adjuvants used in vaccines and are directly related to humoral immune response stimulation and the production of antibodies (JIN al., 2018, NICHOLLS et al., 2010).

Laying hens are potential animals for production of immunobiological molecules, 
especially immunoglobulin Y (IgY) production (FERREIRA JÚNIOR et al., 2018; MUNHOZ et al., 2014). The main adjuvants used for the production of immunoglobulin IgY antibodies in laying hens are complete (CFA) and incomplete (IFA) Freund's adjuvants. However, CFA is associated with tissue necrosis and ulceration, and IFA has a lower immunostimulatory effect (WANKE et al., 1996). Therefore, the identification of immunomodulatory molecules would be a useful tool to study humoral immune response and $\operatorname{IgY}$ production in chickens. However, few studies have explored the impacts of these molecules on immune responses in laying hens. It was shown that the ethanol extract of propolis has an adjuvant effect in laying hens and can be used for the development of novel adjuvants (FREITAS et al., 2011), while sulfated polysaccharides and carboxymethyl glucan have an adjuvant effect on the humoral and cellular immune response in chickens vaccinated against Newcastle disease and avian influenza (GUO et al., 2012; DARPOSSOLO et al., 2010).

Studies in mice have shown that a lectin extracted from the seed of Artocarpus integrifolia, called jacalin (JCA), as well as structural mannoprotein (MPS; extracted from Saccharomyces uvarum), have stimulatory effects on antibody production (ALBUQUERQUE et al., 1999; DARPOSSOLO et al., 2012). The JCA is a galactose-binding lectin that has specificity for human IgA-1 and has a stimulating action on macrophage-related antibody production (ALBUQUERQUE et al., 1999; FELIPE et al., 1995). Mannoprotein (MPS) is a ubiquitous component in the cell walls of yeasts and comprises approximately $15 \%$ proteins that covalently bind to a mannoserich polysaccharide and a small amount of glucose. The main function of MPS is to modulate the permeability of the cell wall, and it is involved in water retention and protects against drying (KLIS et al., 2002). In mice, MPS is associated with increased IFN-gamma production by CD4+ T cells and antibody production (MENCACCI et al., 1994; DARPOSSOLO et al. 2012).

There is a great interest in the production of specific antibodies in laying hens for immunotherapy and immunodiagnostics to replace antibodies produced in mammalians (MONTINI et al., 2018; MARCQ et al., 2015; MARCQ et al., 2013; ETO et al., 2012). Laying hens represent an alternative to mammalians due to the possibility of obtaining large quantities of IgY from egg yolk at a low cost (MUNHOZ et al., 2014). Furthermore, IgY antibodies are functionally similar molecules to mammalian IgGs. They do not interact with the complement system or the Fc receptors in mammals; thereby, reducing their interference in immunoassay and passive immunotherapy protocols (MUNHOZ et al., 2014).

The aim of the research was to investigate the activity of JCA from A. integrifolia and MPS from S. uvarum on antibody production in laying hens.

\section{MATERIALS AND METHODS}

\section{Animals}

In total, 42 White Leghorn hens were used at 40 weeks of life from the Farm School of the State University of Maringá, PR. The animals were kept in cages at room temperature (RT) with food and water ad libitum. The procedure followed the recommendations of the ethics committee for animal experiments at the Universidade Estadual de Londrina, Brazil.

\section{Immunomodulators JCA and MPS}

The JCA sample was extracted from the aqueous extract of the seeds of $A$. integrifolia. The extract was kindly provided by M.C. Roque-Barreira. The MPS of $S$. uvarum was obtained as described in DARPOSSOLO et al. (2012).

\section{Treatment of laying hens}

Initially, 42 hens were distributed randomly into seven groups (6 hens/group). The animals in groups I (GI) and II (GII) were inoculated with phosphate buffered saline (PBS; $0.15 \mathrm{M}, \mathrm{pH}$ 7.2) and 5\% SRBC in PBS, respectively. The animals in groups JCAI, JACII, and JACIII received 0.075 $\mu \mathrm{g}, 0.75 \mu \mathrm{g}$, and $7.5 \mu \mathrm{g}$ of JCA plus $5 \%$ SRBC in PBS, and the animals in groups MPSI and MPSII were inoculated with $20 \mu \mathrm{g}$ and $100 \mu \mathrm{g}$ of MPS plus $5 \%$ SRBC in PBS, respectively. All inoculations were performed intra abdominally on day 1 and were repeated on day 28. On days 7 and 35 of the experiment, serum samples were obtained and stored at $-20{ }^{\circ} \mathrm{C}$ until use.

Immunoassays for the determination of levels of anti$S R B C \operatorname{Ig} Y, \operatorname{Ig} M$, and $\operatorname{Ig} A$

Initially, microplates $\left(\right.$ Costar $\left.^{\circledR} 3590\right)$ were sensitized with $100 \mu$ of protein extract of SRBC at $2.5 \mu \mathrm{g} / \mathrm{mL}$, as described by LADICS, (2007), and kept overnight at $4{ }^{\circ} \mathrm{C}$. Plates were washed with PBS- $-0.05 \%$ and blocked with PBS and 5\% skim powdered milk for 1 hour at RT. Then plates were washed again and the serum samples (1:100) added. After 1 hour at room temperature, plates were washed 
and peroxidase-conjugated with anti-IgY, anti-IgM, or anti-IgA (Bethyl Laboratories, Inc., Montgomery, TX, USA) at dilutions of 1:40,000, 1:5,000, and 1:8,000, respectively; and incubated for 1 hour at RT. Plates were washed and substrate/chromogen $\mathrm{H}_{2} \mathrm{O}_{2}$ (F. Maia, Cotia, SP, Brazil)/3,3',5,5'-tetramethylbenzidine (TMBZ; Sigma-Aldrich Co., St. Louis, $\mathrm{MO}, \mathrm{USA}) /$ sodium acetate buffer $(0.1 \mathrm{M}, \mathrm{pH} 5.0)$ was added and the reaction stopped by the addition of $1 \mathrm{~N} \mathrm{H}_{2} \mathrm{SO}_{4}$. Optical density was determined using a Multiskan reader (Thermo Plate, TP-Reader, Rayto Life, and Analytical Sciences Co. Ltd, Shenzhen, People's Republic of China) at $450 \mathrm{~nm}$ (KILLPACK \& KARASOV, 2012). All analyses were performed in duplicate and each plate contained two antigen-free and serum-free wells, two antigen-free wells with serum, and two wells with antigen and without serum as controls.

\section{Statistical analysis}

Results were analyzed using one-way analysis of variance (ANOVA) by a post hoc Tukey test or Kruskal-Wallis test followed by Dunn's multiple comparison test. A value of $P<0.05$ was considered statistically significant. Prism version 5.01 (GraphPad Software, San Diego, CA, USA) was used for all statistical analyses.

\section{RESULTS AND DISCUSSION}

Jackfruit (Artocarpus heterophyllus, family Moraceae) is a monoecious evergreen tree that grows in several tropical countries. Previously, the purification of human IgA was very tedious, and affinity chromatography on immobilized JAC has become a convenient procedure for its isolation. In recent years, several studies have demonstrated that JAC is important as a lectin with diverse applications, ranging from the isolation of human $\operatorname{IgA} 1$ to applications in acquired immune deficiency syndrome (AIDS) research (KABIR, 1998; MADRUGA et al., 2014).

The main effect of JCA on the mammalian immune system is on lymphocytes. JCA is a potent stimulator of T lymphocyte CD4+ and has an adjuvant effect on antibody responses against soluble antigens and protozoa Trypanosoma cruzi in mice (Albuquerque et al., 1999). The mechanism of action of JCA on the humoral immune response apparently involves stimulation of a $\mathrm{Th} 2$ response due to its interaction with the CD45 molecule of B and T lymphocytes, followed by phosphorylation of mitogen-activated protein kinase p38 and the secretion of interleukin (IL)-4 (TAMMA et al., 2006a; TAMMA et al., 2006b; BABA et al., 2007).
In addition to research conducted with mammals, studies on fish have also demonstrated that JCA exhibits stimulatory action. AHMED et al. (2018) evaluated the capacity of JCA to stimulate antibody production in zebrafish. To verify this hypothesis, the authors performed a radial immunoassay (RIA) using heat-killed A. hydrophila and anti-serum obtained from zebrafish. In their experiments, the anti-serum was collected from infected fish, which demonstrated increased precipitation 21 days post-treatment with JCA; these data suggested a time-dependent effect.

In the current study, three different concentrations were used to evaluate whether JCA action was associated with humoral immunity. Results are shown in figures 1 and 2. Figure 1 presents the levels of anti-SRBC IgM, IgA, and IgYin serum 7 days after the challenge. The results demonstrated that in primary immune response, there was an immunostimulatory effect of JCA on the production of IgY antibodies (Fig 1C), while in secondary immune response there was an immune inhibitory effect of 0.75 and $7.5 \mu \mathrm{g}$ of JCA on IgA antibodies production (Fig $2 \mathrm{~B}$ ). These results suggest that JCA is able to influence antibody production in laying hens.

We also evaluated structural mannoprotein molecules (MPS), which are the complex and multifunctional outer layer of the cell wall of yeasts (Cid et al., 1995). In chickens, there are few studies on mannose receptors on immune cells; but the presence of these receptors in macrophages has been described (ROSSI \& HIMMELHOCH, 1985). It has been reported that the receptor responsible for transporting IgY to the egg yolk is a family member of mannose receptors (HE \& BJORKMAN, 2011). However, the role of these receptors in the immune response of birds remains unknown.

Results obtained when evaluating the impacts of specific antibodies produced in animals inoculated with the MPS/SRBC of $S$. uvarum are shown in Figures 1 and 2. Results demonstrated a reduction in the levels of anti-SRBC $\operatorname{IgM}$ and $\operatorname{IgA}$ in all animals treated with MPS in relation to control group II after the second inoculation. There was a significant reduction in the levels of anti-SRBC IgM in the group inoculated with $100 \mu \mathrm{g}$ of MPS (Figure 2A) and inhibitory production of anti-SRBC IgA in animals treated with $20 \mu \mathrm{g}$ of MPS. This MPSrelated effect was not observed in the production of anti-SRBC IgY 7 days after the challenge (Figure 1). When analyzing the levels of IgY, we did not observe a significant increase in antibody levels in MPS treated groups in relation to the control group inoculated with SRBC. These results suggested that MPS from 


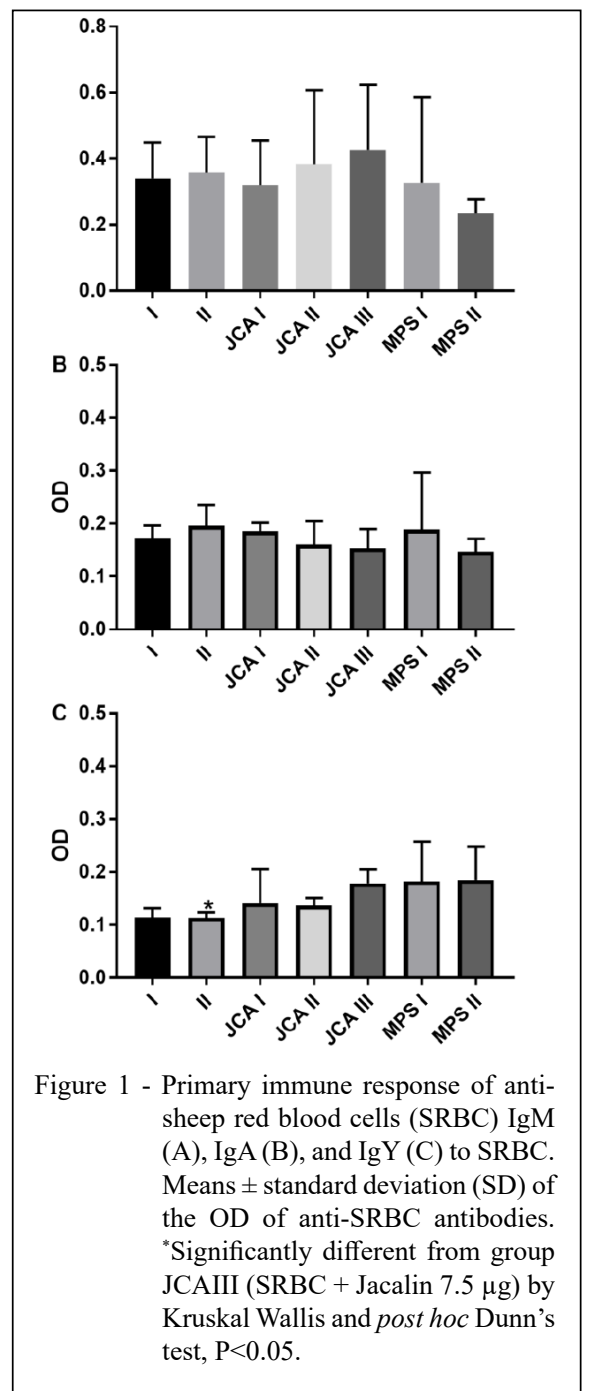

S. uvarum is able to influence the exchange of Ig classes in laying hens, inhibiting the production of IgM and IgA. Although, few studies on the molecular mechanisms involved in the production of specific antibodies have been conducted with chickens, there is evidence that class switching in chickens occurs preferentially in germinal centers and is dependent on the activation signals received by dendritic cells, as in mammals (IMAMURA et al., 2009).

In mammals, these molecules are recognized by mannose receptors located in host macrophages and neutrophils. These receptors participate in the process of phagocytosis and the release of inflammatory mediators (TOROSANTUCCI et al., 1997; STAHL \& EZEKOWITZ, 1998). In mice, when MPS was inoculated with the antigen, the results demonstrated significant increases in the levels of antigen-specific antibodies (DARPOSSOLO et al., 2012). In chickens; although, there are no studies on the effect of MPS inoculation on the humoral immune response, supplementation of their diet with mannose oligosaccharides resulted in increased production of antigen-specific antibodies (HASSAN \& RAGAB, 2007).

In the current study, we observed suppressive action of JCA from $A$. integrifolia and MPS from S. uvarum on the humoral immune response in laying hens. Investigation of the mechanisms associated with the suppressive effects of JCA or effect on production of stimulator IgY of MPS on the humoral immune response may reveal features of the immune response in avians that may be important for the development of new adjuvants for use in poultry. 

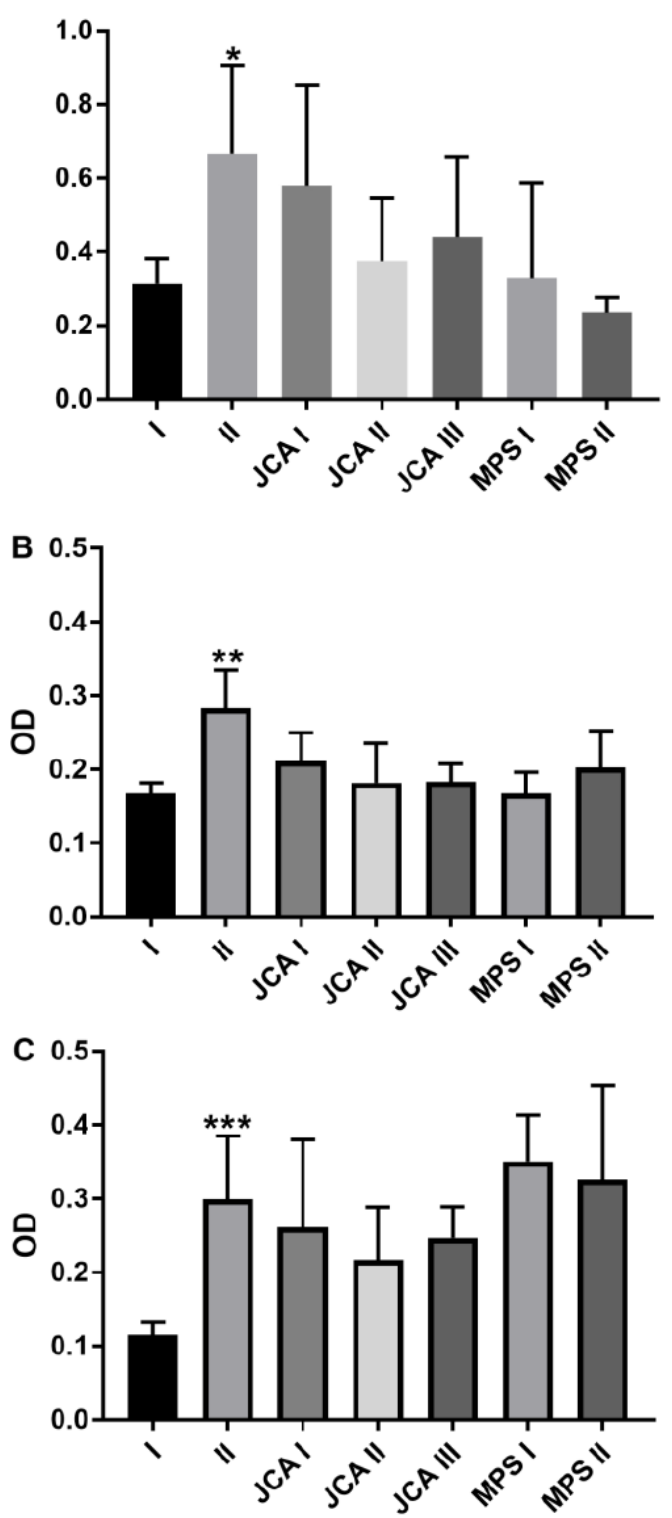

Figure 2 - Secondary immune response of anti-sheep red blood cells (SRBC) $\operatorname{IgM}(\mathrm{A}), \operatorname{IgA}(\mathrm{B})$, and $\operatorname{IgY}$ (C) to SRBC. Means \pm standard deviation (SD) of OD of anti-SRBC antibodies. Significantly different from group I (PBS) and group MPSII $(\mathrm{SRBC}+$ Mannoprotein $100 \mu \mathrm{g})$ by Kruskal Wallis and post hoc Dunn's test, $\mathrm{P}<0.05$. *** Significantly different from GI (PBS), JCAII (SRBC + Jacalin $0.75 \mu \mathrm{g}$ ); JCAIII (SRBC + Jacalin $7.5 \mu \mathrm{g}$ ), and MPSI (SRBC + Mannoprotein $20 \mu \mathrm{g}$ ) by Kruskal Wallis and post hoc Dunn's test, $\mathrm{P}<0.05$. ${ }^{* * *}$ Significantly different from group I (PBS) by one way ANOVA and post hoc Tukey test, $\mathrm{P}<0.05$. 


\section{ACKNOWLEDGEMENTS}

This research was supported by funds from Coordenação de Aperfeiçoamento de Pessoal de Nível Superior (CAPES), Brazil. The authors MACS and MCS received scholarship from Conselho Nacional de Desenvolvimento Científico e Tecnológico (CNPq), Fundação Araucária, Brazil.

\section{BIOETHICS AND BIOSECURITY COMMITTEE APPROVAL}

Protocol 21/11 of the ethics committee for animal experiments at the Universidade Estadual de Londrina.

\section{DECLARATION OF CONFLICT OF INTEREST}

The authors declare no conflict of interest. The founding sponsors had no role in the design of the study; in the collection, analyses, or interpretation of data; in the writing of the manuscript; or in the decision to publish the results.

\section{AUTHORS' CONTRIBUTIONS}

All authors contributed equally for the conception and writing of the manuscript. All authors critically revised the manuscript and approved of the final version.

\section{REFERENCES}

AHMED, K.B.A., et al. Jacalin capped platinum nanoparticles confer persistent immunity against multiple Aeromonas infection in zebrafish. Scientific Reports, vol. 8, Article number: 2200. 2018. Available from: <https://doi.org/10.1038/s41598-01820627-3038/s41598-018-20627-3>. Accessed: Mar. 20, 2019.

ALBUQUERQUE, D.A., et al. The adjuvant effect of jacalin on the mouse humoral immune response to trinitrophenyl and Trypanosoma cruzi. Immunology Letters. 68, 375-381. 1999. doi: 10.1016/s0165-2478(99)00079-6.

BABA, M., et al. Glycosylation-dependent interaction of Jacalin with CD45 induces T lymphocyte activation and Th1/Th2 cytokine secretion. J. Leukoc. Biol. 81, 1002-11. 2007. doi: 10.1189/ jlb.1106660.

CID, V. J., et al. Molecular basis of cell integrity and morphogenesis in Saccharomyces cerevisiae. Microbiol. Rev., 59, 345-386. 1995. PMCID: PMC239365.

DARPOSSOLO, F.P.B., et al. Saccharomyces uvarum mannoproteins stimulate a humoral immune response in mice. Braz. Arch. Biol. Technol. 55, 597-602. 2012. Available from: <https://doi.org/10.1590/S1516-89132012000400016>. Accessed: Mar. 20, 2019.

DARPOSSOLO, F.P.B., et al. Evaluation of potential immunostimulant of the Carboxymethyl-glucan from Saccharomyces cerevisiae in poultry (Gallus domesticus). Semina: Ciências Agrárias. 31, 231-240, 2010. Available from: <http://www.uel.br/revistas/uel/index.php/semagrarias/article/ viewFile/4911/4369>. Accessed: Mar. 20, 2019.
ETO, S.F., et al. Effect of inoculation route on the production of antibodies and histological characteristics of the spleen in laying hens. Braz. J. Poultry Sci., 14, 63-66. 2012. Available from: $<$ https://doi.org/10.1590/S1516-635X2012000100011>. Accessed: Mar. 20, 2019.

FELIPE, I., et al. Increased clearance of Candida albicans from the peritoneal cavity of mice pretreated with concanavalin A or jacalin. Braz. J. Med. Biol. Res. 28, 477-483. 1995. PMID: 8520546.

FERREIRA JÚNIOR, Á., et al. Gallus gallus domesticus: immune system and its potential for generation of immunobiologics. Ciência Rural, 48, e20180250. 2018. Available from: $<$ https://doi. org/10.1590/0103-8478cr20180250>. Accessed: Mar. 20, 2019.

FREITAS, J. A, et al. The effects of propolis on antibody production by laying hens. Poult. Sci. 90, 1227-1233. 2011. Available from: $<$ https://doi.org/10.3382/ps.2010-01315>. Accessed: Mar. 20, 2019.

GUO, L., et al. Adjuvanticity of compound polysaccharides on chickens against Newcastle disease and avian influenza vaccine. Int. J. Biol. Macromol. 50, 512-7. 2012. Available from: $<$ https:// doi.org/10.1016/j.ijbiomac.2012.01.002>. Accessed: Mar. 20, 2019

HASSAN, H.A., RAGAB, M.S. Single and combined effects of mannan oligosaccharide (mos) and dietary protein on the performance and immunity response of laying hens. Egypt. Poult. Sci. 27, 969-987. 2007.

HE, Y. \& BJORKMAN, P.J. Structure of FcRY, an avian immunoglobulin receptor related to mammalian mannose receptors, and its complex with IgY. Proc. Natl. Acad. Sci. U S A. 108, 12431-12436. 2011. Available from: <https://doi.org/10.1073/ pnas.1106925108>. Accessed: Mar. 20, 2019.

IMAMURA, K., et al. Characteristic cellular composition of germinal centers. Comp. Immunol. Microbiol. Infect. Dis. 32, 419-428. 2009. Available from: <https://doi.org/10.1016/j. cimid.2007.12.002>. Accessed: Mar. 20, 2019.

JIN, Y, et al. $\beta$-glucans as potential immunoadjuvants: A review on theadjuvanticity, structure-activity relationship and receptor recognitionproperties. Vaccine, 36, 5235-5244. 2018. Available from: < https://doi.org/10.1016/j.vaccine.2018.07.038>. Accessed: Mar. 20, 2019.

KABIR, S. Jacalin: a jackfruit (Artocarpus heterophyllus) seedderived lectin of versatile applications in immunobiological research. J. Immunol. Methods. 212, 193-211. 1998. Available from: <https:// doi.org/10.1016/S0022-1759(98)00021-0>. Accessed: Mar. 20, 2019.

KILLPACK, T.L. \& KARASOV, W.H. Ontogeny of Adaptive Antibody Response to a Model Antigen in Captive Altricial Zebra Finches. PLOS ONE. Published: October 9, Available from:<https://doi.org/10.1371/journal.pone.0047294>, 2012. Accessed: Mar. 20, 2019.

KLIS, F.M., et al. Dynamics of cell wall structure in Saccharomyces cerevisiae. FEMS Microbiol. Rev. 26, 239-56. 2002. Available from: $\quad<$ https://doi.org/10.1111/j.1574-6976.2002.tb00613.x>. Accessed: Mar. 20, 2019.

LADICS, G.S. Use of SRBC antibody responses for immunotoxicity testing. Methods, 41(1):9-19. 2007. Available from: $<$ https://doi. org/10.1016/j.ymeth.2006.07.020>. Accessed: Mar. 20, 2019. 
MADRUGA, M.S., et al. Chemical, morphological and functional properties of Brazilian jackfruit (Artocarpus heterophyllus L.) seeds starch. Food Chemistry. 143, 40-445. 2014. Available from: $<$ https://doi.org/10.1016/j.foodchem.2013.08.003>. Accessed: Mar. 20, 2019.

MARCQ, C., et al. Improving adjuvant systems for polyclonal egg yolk antibody (IgY) production in laying hens in terms of productivity and animal welfare. Vet. Immunol. Immunopathol., 165, 54-63. 2015. Available from: <https://doi.org/10.1016/j. vetimm.2015.02.012>. Accessed: Mar. 20, 2019.

MARCQ, C., et al. Refinement of the production of antigenspecific hen egg yolk antibodies (IgY) intended for passive dietary immunization in animals. A review. Biotechnol. Agron. Soc. Environ. 17, 483-493. 2013. Available from: <http://hdl.handle. net/2268/144665>. Accessed: Mar. 20, 2019.

MASIHI, K.N. \& SCHÄFER, H. Overview of Biologic Response Modifiers in Infectious Disease. Infect. Dis. Clin. North. Am. 25, 723-731. 2011. Available from: <https://doi.org/10.1016/j. idc.2011.07.002>. Accessed: Mar. 20, 2019.

MENCACCI, A., et al. A mannoprotein constituent of Candida albicans that elicits different levels of delayed-type hypersensitivity, cytokine production, and anticandidal protection in mice. Infect Immun. 62, 5353-60. 1994. Available from: <https://iai.asm.org/ content/iai/62/12/5353.full.pdf $>$. Accessed: Mar. 20, 2019.

MONTINI, M.P.O., et al. Effects of inoculation route and dose on production and avidity of IgY antibodies. Food Agr. Immunol., 29, 306-315. 2018. Available from: <https://doi.org/10.1080/0954 0105.2017.1376036>. Accessed: Mar. 20, 2019.

MUNHOZ, L.S., et al. Avian IgY antibodies: characteristics and applications in immunodiagnostic. Ciência Rural, 44, 153160. 2014. Available from: <https://doi.org/10.1590/S010384782014000100025>. Accessed: Mar. 20, 2019.
NICHOLLS, E.F., et al. Immunomodulators as adjuvants for vaccines and antimicrobial therapy. Ann. N. Y. Acad. Sci. 1213, 46-61. 2010. Available from: <http://www.cmdr.ubc.ca/bobh/ wp-content/uploads/2016/11/428.-Nicholls-2010.pdf $>$. Accessed: Mar. 20, 2019.

ROSSI, G. \& HIMMELHOCH, S. Immunocytochemical localization of the mannose receptor on ultrathin cryo sections of chicken macrophages. Eur. J. Cell. Biol. 38, 280-291. 1985. PMID: 3899646.

STAHL, P.D. \& EZEKOWITZ, R.A. The mannose receptor is a pattern recognition receptor involved in host defense. Curr. Opin. Immunol. 10, 50-5. 1998. Available from: $<$ https://doi. org/10.1016/S0952-7915(98)80031-9>. Accessed: 20, 2019.

TAMMA, S.M.L., et al. The lectin jacalin plus costimulation with anti-CD28 antibody induces phosphorylation of p38 MAPK and IL-4 synthesis-I. J. Leukoc. Biol. 79, 876-880. 2006a. Available from: $<$ https://doi.org/10.1189/jlb.0905512>. Accessed: Mar. 20, 2019.

TAMMA, S.M.L., et al. p38 MAPK plays a role in IL-4 synthesis in jacalin plus CD28-stimulated CD4+ T cells--II. J. Leukoc. Biol. 79, 1339-47. 2006b. Available from: <https://doi.org/10.1189/ jlb.0905513>. Accessed: Mar. 20, 2019.

TOROSANTUCCI, A., et al. Responsiveness of human polymorphonuclear cells (PMNL) to stimulation by a mannoprotein fraction (MP-F2) of Candida albicans; enhanced production of IL-6 and tumour necrosis factor-alpha (TNF-alpha) by MPF2-stimulated PMNL from HIV-infected subjects. Clin. Exp. Immunol. 107, 451-7. 1997. Available from: <https://doi.org/10.1 046/j.1365-2249.1997.2851176.x>. Accessed: Mar. 20, 2019.

WANKE, R., et al. Freund's complete adjuvant in the chicken: efficient immunostimulation with severe local inflammatory reaction. Zentralbl Veterinarmed A. 43, 243-53. 1996. PMID: 8767734 . 